DOI 10.37882/2223-2982.2021.10.30

\title{
СПЕЦИФИКА ПОЗНАНИЯ И УСВОЕНИЯ СОДЕРЖАНИЯ АУТЕНТИЧНЫХ ТЕКСТОВ НА ЗАНЯТИЯХ ПО РУССКОМУ ЯЗЫКУ КАК ИНОСТРАННОМУ
}

\section{THE SPECIFICS OF COGNITION AND ASSIMILATION OF THE CONTENT OF AUTHENTIC TEXTS IN RUSSIAN AS A FOREIGN LANGUAGE CLASSES \\ N. Serebrennikova E. Miloserdova}

Summary: The article considers the features of studying authentic texts in the lessons of Russian as a foreign language, justifies the relevance of referring to such texts. A system of tasks and exercises that contribute to the development of important speech skills is given.

Keywords: authentic text, speech communication, speech skills, pre-text tasks, pre-text tasks, after text tasks.

\author{
Серебренникова Надежда Геннадиевна \\ К.филол.н., ФГБОУ ВО «Тамбовский государственный \\ университет имени Г.Р. Державина» \\ Nadegda_korrespondensija@mail.ru \\ Милосердова Елена Михайловна \\ К.филол.н., ФГБОУ ВО «Тамбовский государственный \\ университет имени Г.Р. Державина»
}

Аннотация: В статье рассматриваются особенности изучения аутентичных текстов на уроках русского языка как иностранного, обосновывается актуальность обращения к таким текстам. Приводится система заданий и упражнений, способствующих развитию важных речевых навыков.

Ключевые слова: аутентичный текст, речевое общение, речевые навыки, предтекстовые задания, притекстовые задания, после текстовые задания.

тентичным текстам, т.е. к таким, «которые были созданы носителями языка именно для носителей данного языка в условиях естественного речевого общения» [6, с. 11]. Слово «аутентичный» означает «действительный, подлинный» [7, с. 32]. Подобные тексты изначально не предназначены для учебного процесса, это неадаптированные тексты, они могут передавать культурные аспекты, образцы речевого поведения носителей языка. Данные тексты максимально приближают студентов, изучающих язык, к ситуации живого общения [4; 3, с. 8].

Аутентичные тексты можно изучать на любом этапе, в том числе и на начальном, но наиболее целесообразным является обращение к ним на среднем и более позднем этапах, поскольку студенты уже будут иметь необходимый словарный запас и знание грамматических конструкций. Аутентичные тексты в любом случае гораздо сложнее, чем адаптированные, поэтому рекомендуется начинать с небольших по объему произведений, которые бы не содержали слишком много неизвестной для студентов лексики и не были бы перегружены сложными грамматическими конструкциями. Желательно также, чтобы тексты в плане содержания были актуальны для учащихся, вызывали у них неподдельный интерес, а также, по возможности, были бы связаны с их профессиональной деятельностью. Как справедливо отмечает И.И. Сарычева, «наглядность материалов, неординарные сюжеты вовсе не являются залогом успеха, если обучаемые не прослеживают связи между изучаемым материалом и его применением в естественных условиях в повсед- 
невном и профессиональном общении» [8, с. 100]. Для формирования определённых речевых навыков необходимо применение системы заданий, способствующих лучшему пониманию неадаптированных текстов. Необходима при этом обращаться ко всем видам речевой деятельности - чтению, говорению, аудированию, письму. Важно также уделить внимание страноведческому, лингвокультурному аспектам.

Правильным с методической точки зрения будет предложить учащимся тексты, содержащие несложные грамматические конструкции, которые не затрудняют понимание текста, а в дальнейшем могут быть использованы студентами для его воспроизведения.

Работа с аутентичными текстами на уроках проходит в несколько этапов и включает в себя предтекстовые, притекстовые и послетекстовые задания. При помощи предтекстовых заданий устраняются речевых трудностей, которые могут возникнуть у учащихся при прочтении и понимании текста. Они также должны способствовать формированию определённых навыков работы с трудным текстом, когда не все слова, встречающиеся в произведении, понятны студентам. Основная цель при этом - выработка умения не обращать внимание на языковые трудности, воспитание навыков межкультурного общения. Нельзя забывать, что, прежде всего, у обучающихся должно появиться желание прочитать тот или иной текст, т.к. заинтересованность делает работу намного эффективнее. Предтекстовые упражнения могут быть построены таким образом, чтобы можно было понять, насколько студенты готовы воспринимать данное произведение. Преподавателю иногда необходимо с этой целью дать студентам сведения об авторе и времени, когда было написано то или иное произведение, или познакомить их с творчеством писателя. Можно попросить учащихся дать ответ на вопрос о том, известен ли этот автор в их стране.

Для предтекстовых заданий необходимо организовать отбор определённых лексических единиц. Нужно объяснить лексику, которая несёт культурную информацию, обратить внимание на те слова, которые выражают авторское отношение к персонажам. Если в тексте имеются иллюстрации или ссылки или какие-либо другие пояснения, то на них также необходимо обратить внимание учащихся.

Лексический материал по возможности может быть объяснен с использованием наглядности. Необходимо также вырабатывать навыки понимания новой лексики, прибегая к семантизирующему контексту. К предварительной работе также относится работа с заголовком и структурой текста. Таким образом, предтекстовые задания могут включать в себя следующие упражнения:

- ознакомиться со сведениями об авторе текста, сведениями о его произведениях;

- ознакомиться с новыми словами и грамматическими конструкциями текста (определить значения слов, используя знания родного языка, прочитать словосочетания и группы слов и определить значения выделенных слов, прочитать фразы и определить значение выделенных слов с помощью контекста);

- посмотреть на иллюстрации и сказать, о чем, возможно, пойдет речь в произведении;

- определить содержание текста по названию, или определить содержание текста, выбрав из предложенных формулировок.

Следующим этапом является непосредственное чтение текста и выполнение притекстовых упражнений. В данном случае, в зависимости от сложности текста, преподаватель может сформулировать следующие задания:

- прочитать текст полностью, во время чтения не пользоваться словарем;

- прочитать текст полностью, во время чтения можно использовать словарь, чтобы уточнить значение некоторых непонятных слов;

- прочитать текст по абзацам и сообщить, о чем идёт речь в каждом из абзацев;

- прочитать первый абзац и выделить предложение, которое передаёт основную информацию;

- прочитать произведение и отметить слова, несущие основную смысловую нагрузку;

- прочитать каждый из абзацев и сформулировать основное значение отрывка отдельным предложением.

Далее могут следовать послетекстовые задания, направленные на выяснение, понятно ли общее содержание текста учащимся. Это может быть упражнение в виде теста, где студентам предлагается ответить на вопросы по содержанию текста, выбрав правильный вариант. Учащимся также может быть предложено распределить вопросы или утверждения в последовательности, которая соответствует содержанию произведения.

Послетектовые задания обязательно должны включать в себя упражнения на усвоение новых изученных слов, словообразовательных моделей, грамматических конструкций. Например, задания, в которых необходимо подобрать к уже знакомым словам синонимы и антонимы, которые встречаются учащимся в изучаемом тексте. Можно также попросить подобрать к уже известным словам новые слова с уменьшительно-ласкательными суффиксами. Преподаватель также может дать задание учащимся составить предложения, содержащие определённые грамматические конструкции.

Но наиболее важным на данном этапе является умение выражать и правильно формулировать своё отноше- 
ние к содержанию текста. Цель данного этапа - формирование умения смысловой переработки текста. В данном случае можно использовать следующие упражнения:

- учащимся предлагается сказать, согласны ли они или нет с определенными утверждениями;

- студенты должны пояснить, что, по их мнению, означает заголовок текста и, если это возможно, дать произведению другое название;

- сформулировать основную мысль текста;

- рассказать об обстановке, в которой жили персонажи текста;

- описать мысли или чувства главных героев;

- выразить своё отношение к персонажам произведения.
Упражнения, направленные на работу с аутентичным текстом, должны охватывать все виды речевой деятельности. Небольшие по объёму и достаточно простые с точки зрения изучаемой лексики и грамматики аутентичные тексты способны вывести речевые умения учащихся на новый уровень, так как они развивают ассоциативное мышление, способствуют формированию умений выражать свои мысли, повышают интерес к изучению иностранного языка. Главной целью является подготовка студентов к речевому общению в естественных условиях, а процесс обучения будет только тогда эффективным, когда учащиеся смогут изучать естественную живую речь носителей языка, широко представленную в аутентичных текстах.

\section{ЛИТЕРАТУРА}

1. Агманова А.Е. Текст как основа моделирования межкультурного общения / А.Е. Агманова // Текст в системе обучения русскому языку и литературе: материалы международной научно-методической конференции / Отв. ред. Е.А. Журавлева. - Астана: Изд-во ИП «Дана», 2018. - 300 с.

2. Барсегян К.М. Использование аутентичных материалов вне языковой среды (вьетнамские учащиеся, начальный этап) / К.М. Барсегян // Сборник материалов XVIII международной научно-практической конференции «Язык, культура, менталитет: проблемы изучения в иностранной аудитории», РГПУ им. А.И. Герцена, Санкт-Петербург, 2019.

3. Барсукова-Сергеева 0.М. Читая сказки...: учеб. пособие / 0.М. Барсукова-Сергеева. - М.: Флинта: Наука, 2009. - 200 с.

4. Ковалева Н.А. Работа с художественным текстом на уроках РКИ (особенности восприятия) / Н.А. Ковалева, Н.Л. Вертунова // Цивилизация знаний: российские реалии. Материалы XVI Международной научной конференции (РосНОУ, ИНИОН РАН, ЦЭМИ РАН), апрель 2017. - М. - С. $269-274$.

5. Крючкова Л.С. Практическая методика обучения русскому языку как иностранному / Л.С. Крючкова. - М..: Флинта: Наука, 2012 . - 480 с.

6. Кулибина Н.В. Зачем, что и как читать на уроке. Художественный текст при изучении русского языка как иностранного / Н.В. Кулибина. - СПб.: Златоуст, 2011. $-264 c$.

7. Ожегов С.И. Толковый словарь русского языка / С.И. Ожегов, Н.Ю. Шведова. - М.: Азбуковник, 1999. - 944 с.

8. Сарычева И.И. Использование аутентичных текстов в обучении иностранному языку студентов нелингвистических специальностей) / И.И. (арычева // Вестник науки и образования. - 2018 - N 12(48). - С. 100-103.

( Серебренникова Надежда Геннадиевна (Nadegda_korrespondensija@mail.ru), Милосердова Елена Михайловна. Журнал «Современная наука: актуальные проблемы теории и практики» 